\title{
Glioblastoma cancer stem cells: Basis for a functional hypothesis
}

\author{
Davide Schiffer ${ }^{1^{*}}$, Marta Mellai ${ }^{1}$, Laura Annovazzi ${ }^{1}$, Angela Piazzi $^{1,2}$, Oriana Monzeglio ${ }^{1}$, \\ Valentina Caldera ${ }^{1}$ \\ ${ }^{1}$ Neuro-Bio-Oncology Center, Policlinico di Monza Foundation (Vercelli)/Consorzio di Neuroscienze, University of Pavia, Pavia Italy; \\ *Corresponding Author: davide.schiffer@unito.it \\ ${ }^{2}$ Department of Medical Sciences, University of Piemonte Orientale, Novara, Italy
}

Received 9 April 2012; revised 10 May 2012; accepted 10 June 2012

\section{ABSTRACT}

GBM Cancer stem cells (CSCs) are responsible for growth, recurrence and resistance to chemoand radio-therapy. They are supposed to originnate from the transformation of Neural stem cells (NSC) of the Sub-ventricular zone (SVZ) or Sub-granular zone (SGZ) of hippocampus. Alternatively, they can be the expression of a functional status of competence or dedifferentiated cells of the tumor re-acquiring stemness properties. The origin of gliomas has been put in relation with the primitive neuroepithelial cells of the SVZ or NSC or progenitors, as showed by the development of experimental tumors in rats by transplacental ethylnitrosourea administration. The demonstration of CSCs in GBM is based on Neurosphere (NS) and Adherent cell (AC) development in culture. NS share the same genetic alterations with primary tumors and express stemness antigens, whereas AC show differentiation antigens. NS are generated by the most malignant areas of GBM. CSCs are considered at the top of a hierarchy of tumor cells of which the most immature are Nestin ${ }^{+} / C D 133^{-}$ cells or established on the basis of EGFR amplification or delta-EGFR. NS in serum conditions differentiate and give origin to $A C$, the real nature of which is still a matter of discussion. Cells in culture could be simply in vitro entities depending on culture methodology. CSCs in GBM could be tumor cells at the end of a dedifferentiation process re-acquiring stemness properties, in an opposite way to what is realized in normal cytogenesis, where stemness is lost progressively with cell differentiation. This interpretation could fit with the origin of the two GBM types, primary and secondary. In primary GBM the tumor originates directly from stem cells or progenitors from SVZ with an accelerated transformation, whereas secondary GBM originates by transformation from astrocytomas arisen through a slow transformation from $\mathrm{mi}-$ grating stem cells and progenitors.

Keywords: Glioblastoma; Stemness; Origin

\section{INTRODUCTION}

In the last decade a tremendous amount of contributions has been dedicated to the problem of Cancer stem cells (CSCs). In Glioblastoma (GBM) they have been repeatedly demonstrated, interpreted and discussed in relation with the methodology of culture and the starting concepttual viewpoint of the authors. Depending on their attitude as specialists of the field, pathologists/neuro-pathologists, neurobiologists or researchers simply using in vitro culture CSCs for resolving neuro-oncological problems, different opinions have been put forward going from CSCs as a special cell type to CSCs as a functional state or a sheer product of the culture. We wanted in this study to discuss the nature of CSCs on the basis of our experience of neuropathologists/neuro-oncologists based on the daily practice with CSCs in the context of diagnosis, genesis and prognosis of gliomas.

\section{NERVOUS CYTOGENESIS AND CANCER STEM CELLS}

As in other malignancies, in gliomas, Cancer stem cells (CSCs) represent a subset of rare tumor cells capable of self-renewal, tumorigenicity, differentiation and tumor regeneration [1-3] and at the top of a hierarchy of tumor cells [4]. They are supposed to originate from the transformation of Neural stem cells (NSCs), but also from restricted progenitors or more differentiated cells, capable of restoring self-renewal [5-7]. Their source has been identified in the germinal matrices, Sub-ventricular 
zone (SVZ) or Sub-granular zone (SGZ) of the hippocampus. At variance, they may represent a functional status [8] or dedifferentiated tumor cells which re-acquire stem cell-like properties $[2,9,10]$. As a matter of fact, gliomas have been produced from dedifferentiated astrocytes [11,12]. Even thought different from the Tumor initiating cells (TICs), identified in the early stages of the tumor, with less mutations and not yet showing the full characteristics of CSCs [13], the two terms are often used inter-changeably [14] also for Glioblastoma multiforme (GBM) $[15,16]$.

CSCs are generally considered as the real target of tumor therapies and from the neuropathologic view point, they are considered in the context of brain function and pathology and under the influence of microenvironments [17].

In the Central nervous system (CNS), NSCs and progenitors occur from the embryo to the adult. Primitive neuroepithelial cells reside in the germinative matrix and give origin to basal progenitors and radial glia, which are found in the telencephalon and generate neurons. In the adult, NSCs are found in the SVZ of the hemispheres, in niches with specific microenvironments [18], composed of $\mathrm{A}, \mathrm{B}$ and $\mathrm{C}$ cells (neuroblasts, quiescent NSCs and transit-amplifying cells, respectively), surrounded by ependymal cells. They are in contact with vessels and send an apical process toward the ventricle, for the stemness maintenance [19]. One of the function of the niche is exactly that to preserve stemness of NSCs [20]. In the mouse, ependymal cells may exist expressing CD133/CD24 and capable of generating neurons, astrocytes and oligodendrocytes [21].

Some cells of GBM show markers of neural progenytors/stem cells, so that its CSCs are considered as deriveing from multipotent NSCs and responsible for growth, recurrence and resistance to therapies, as in other malignnancies. To the first evidence that NSCs of the SVZ are involved in gliomagenesis [22,23], many studies pointed out the glioma origin from aberrant NSCs [2,24-28] and this was confirmed by experiments on animal models [29].

The origin of gliomas from the primitive neuroepithelial cells was demonstrated years ago by the experimenttal production of brain tumors in the rat with nitrosourea derivatives [30]. Ethylnitrosourea (ENU) was administered to the mother rat at the 17th day of gestation and Methylnitrosourea (MNU) to the adult rat [31]. In the first case tumors developed in the offspring migrating from the germinative matrices, proliferating and differentiating. The tumors appeared in the future hemispheres after some cell generations $[22,23]$. The latency period between the first hit, at the $17^{\text {th }}$ day of gestation, and the first tumor development, was roughly two months and it corresponded in man to the period from i.u. life to the fourth or fifth decade of e.u. life when astrocytomas appear. Tumors by MNU developed from the SVZ or from the SGZ of the hippocampus.

\section{THE NATURE OF CSCS AND THE NICHES}

GBMs are heterogeneous tumors with undifferentiated and differentiated glia cells and a genetic resemblance with NSCs, beside genetic alterations of the tumor transformation. The demonstration of CSCs in GBM is given by the formation of Neurospheres (NS) in culture media containing growth factors, sharing genetic properties with the primary tumor and antigenic properties with NSCs $[32,33]$. Adherent cells (AC) develop in serumcontaining media which do not show the genetic properties of the tumor and express differentiation antigens [33-35].

The expression by CSCs of the surface glycoprotein CD133, is discussed as representative of stemness and conditioning tumorigenesis $[28,36]$. The differentiation between + and - cells, based on cell sorting, which is not exempt from impurity problems, is a problem [16]. However, it could be of marginal interest in comparison with other aspects, for example, the Phosphatase and tensin homolog (PTEN) status which correlates with NS growth. $\mathrm{CD}_{133^{+}}$and $\mathrm{CD} 133^{-}$cells form distinct self-renewing populations, hierarchically organized with $\mathrm{CD}_{133^{-}}$/ $\mathrm{Nestin}^{+}$as the most immature cells. Cells expressing a range of markers could contribute to the aggressive growth of individual tumors [16]. A CSC hierarchy has been recognized also on the basis of amplified Epidermal growth factor receptor (EGFR) or delta-EGFR [37].

In the SVZ of the mouse, $\mathrm{CD} 133^{+} / \mathrm{CD} 24^{+}$ependymal cells [21] form a second NSC population composed of and there is a high degree of plasticity in the of exchange between ependymal cells and astrocytes [38]. However, the stage-specific embryonic antigen-1 (SSEA1/CD15) [39] is not expressed in ependymal cells, but it can be positive in ependymoma-derived NS and ependymomas [38]. Among the many regulatory factors of CSCs and NSCs, B lymphoma Mo-MLV insertion region 1 homolog (BMI1) regulates p16 and p19 [40] and is largely expressed in gliomas [41] where it supports invasiveness.

Niches represent a crucial point in the relationship between GBM and its CSCs. To the SVZ [42] and SGZ of hippocampus [43] as niches for NSCs, the white matter could be added as well [44]. Stem cells and quiescent cells are regulated through a balance between proliferation and anti-proliferation signals [45] from which genetic events free cells for tumorigenesis [46]. There is a co-regulation between NSCs and vessels $[19,20]$ and the same happens between microvasculature, cell proliferation and aggressiveness in GBM tumoral niches where stem cells through Vascular endothelial growth factor 
(VEGF) support angiogenesis which in turn maintains stem cell survival $[47,48]$, and hypoxia is crucial for both phenomena $[49,50]$. Proliferating tumor cells are supported by the activation of Hypoxia-inducible factor 1 (HIF-1) which regulates VEGF and platelet-derived growth factor B (PDGF-B) [51,52]. Subsets of Vascular endothelial (VE)-cadherin-positive (CD144 ${ }^{+}$) cells showing CSCs features are capable to start de novo vascularisation by differentiating into endothelial cells $[53,54]$.

Stem cells in the adult can be attracted from gliomas $[55,56]$, likely by inflammatory mediators secreted in the damaged CNS from tumor cells, for example, C-X-C chemokine receptor type 4 (CXCR4) [57,58]. Migrating transformed stem cells can be attracted by hypoxia in a neo-niche with its specialized microenvironment [59] or they may contribute to the tumor mass.

Resistance to radio- and chemo-therapy is a feature of CSCs and it is one of the factors responsible for the failure of local control of GBM. Resistance to radio-therapy could be ascribed to the activation of the DNA damage response machinery that increases survival [46]. Inhibition of Checkpoint 1/Checkpoint 2 kinases (Chk1/Chk2) and Poly (ADP-ribose) polymerase 1 (PARP1) make the cells more vulnerable to radiation [60,61]. After irradiation, $\mathrm{CD} 133^{+}$cells accumulate in the irradiated areas [62] through the role played by BMI1 [63].

\section{OUR EXPERIENCE ON CSCS AND ON THEIR IDENTIFICATION}

In our collection of 21 GBM cell lines, NS developed in growth factor containing media and $\mathrm{AC}$ in serum condition in 10 and in 13 cases respectively. NS showed the same genetic alterations and stemness antigens, such as CD133, Musashi.1, Nestin, SOX2 and REST [33] as primary tumors whereas AC expressed differentiation antigens, such as GFAP, Galacto-cerebroside (GalC) and $\beta$-III Tubulin [33] (Figure 1, Tables 1 and 2). With the addition of serum to the medium, NS differentiated showing the same antigens as AC. In one case both cell types developed and in another case NS could be obtained from AC by the addition of factors. Our results corresponded, more or less, to previous ones [34,35]: In growth factor containing media NS grew and behaved like NSCs, with clonogenicity and tumorigenicity and with a gene expression profile similar to that of primary tumors; in serum containing media adherent cells developed with no resemblance either to NSCs or primary tumors. They were clearly differentiated.

Microarray studies showed a new categorization of GBM with three subtypes: A Proneural type (PN) with genes of normal brain and neurogenesis and a better prognosis; A Proliferation type (Prolif) with genes of cell proliferation and of poor prognosis and a mesenchymal
Table 1. Stemness and differentiation antigens in glioblastomas and cell lines.

\begin{tabular}{lccc}
\hline Antigens & Primary tumors & Neurospheres & $\begin{array}{c}\text { Adherent } \\
\text { cells }\end{array}$ \\
\hline CD133 & + & ++ & - \\
Musashi.1 & + & + & - \\
Nestin & ++ & ++ & - \\
SOX2 & ++ & ++ & - \\
GFAP & + - & - & + \\
GalC & - & - & + \\
$\beta$-III Tubulin & - & - & + \\
\hline
\end{tabular}

Table 2. Molecular genetics in glioblastomas and cell lines.

\begin{tabular}{lccc}
\hline & $\begin{array}{c}\text { EGFR } \\
\text { amplification }\end{array}$ & $\begin{array}{c}\text { PTEN } \\
\text { mutations }\end{array}$ & $\begin{array}{c}\text { TP53 } \\
\text { mutations }\end{array}$ \\
\hline Primary tumors & + & + & \pm \\
Neurospheres & + & + & \pm \\
Adherent cells & - & \pm & - \\
\hline
\end{tabular}

type (Mes) with genes of angiogenesis activation and poor prognosis [64]. In culture, cell clusters were identified corresponding to the NS and AC showing neurodevelopmental genes and extra-cellular matrix related genes and high and low tumorigenicity, respectively. GBM would be composed by the two phenotypes [34]. Serum cells, even if regaining tumorigenicity in later passages, underwent significant genomic alterations, genetically and biologically different from primary tumors.

NS appear to be the true CSCs and the relevant stem cell property goes lost when they are put in serum conditions; it is restored with the addition of growth factors, but it is very unlikely that they could have preserved the stem cell properties [35]. There are intermediate behaveiours between NS and AC [34]. One wonders, therefore, whether AC are endowed with a partial stemness and what they really are. Monolayer systems of culture, i.e. plating NSCs on ornithine, laminin or fibronectin and making them grow flat and adherent with all the features of NS, give different views on CSCs summarized by the sentence "going round or going flat" $[65,66]$. It would be impossible to compare each other the results of both procedures also taking into account that it is not excluded that NSCs could be nothing else than "physiological players" or in vitro entities [67], in line with the repeatedly emphasized concept that culture methodology can influence the expression of CSCs $[66,68]$. Also in our culture conditions, a hierarchy of CSCs can exist, based not only on molecular features, but also on growth rate, clonogenicity and tumorigenicity, i.e. concerning stemness and aggressiveness or differentiation. 


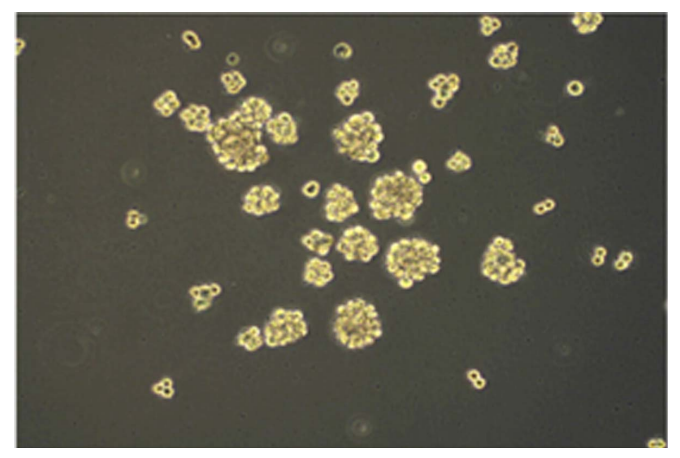

(a)

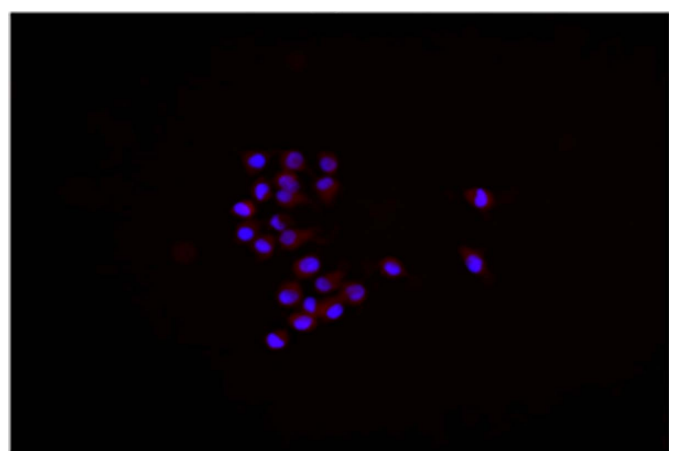

(c)

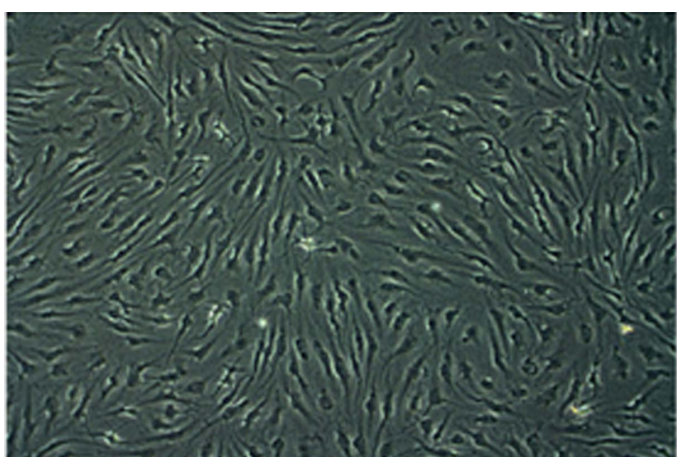

(e)

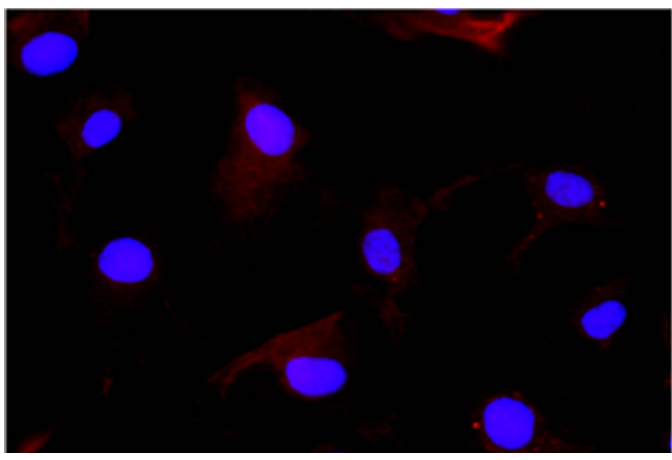

(g)

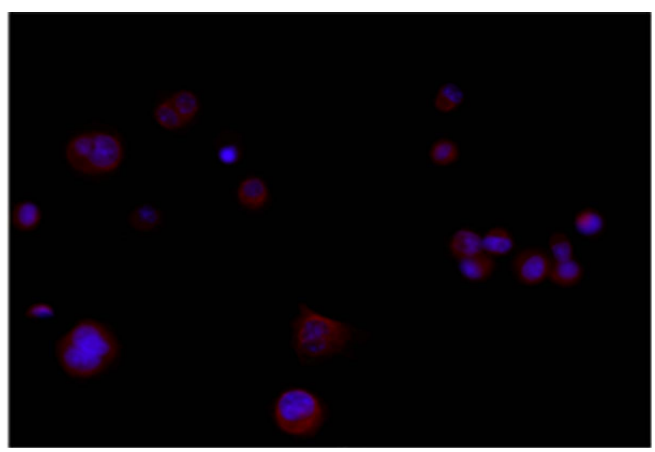

(b)

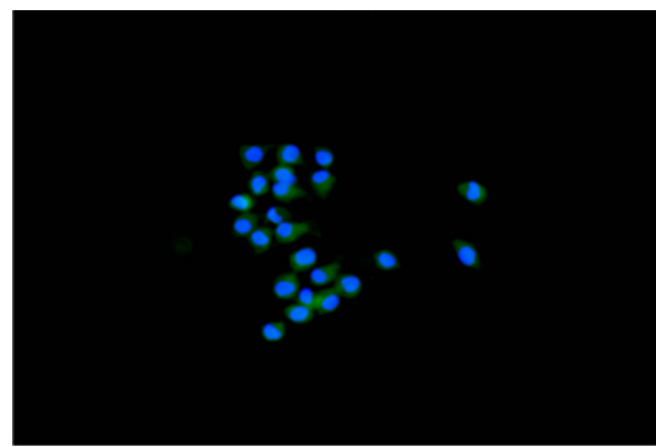

(d)

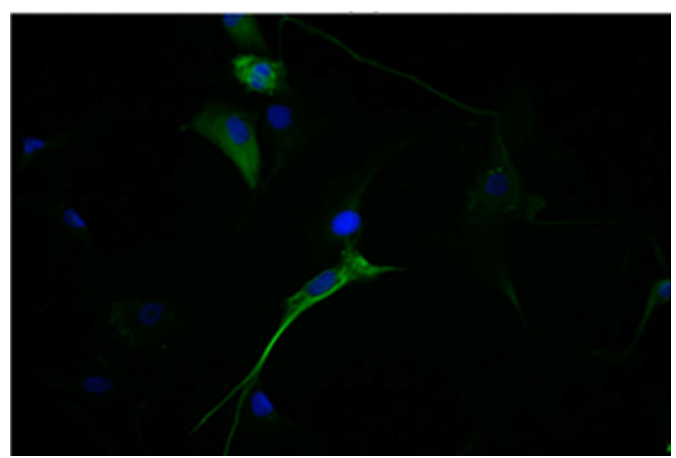

(f)

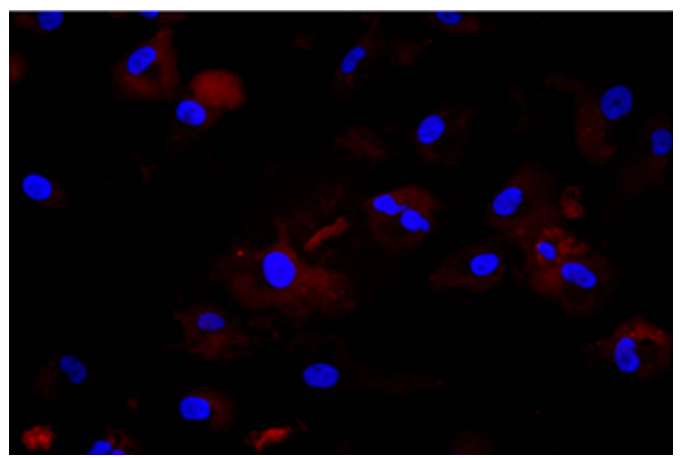

(h)

Figure 1. (a) Neurospheres in DMEM/F-12 medium with growth factors (10× magnification); (b) Nestin expression in cytoplasms. Nuclei are counterstained with DAPI (40× magnification); (c) Id. CD133 (20× magnification); (d) Id. Musashi.1 (20× magnification); (e) Adherent cells in DMEM with serum (10× magnification); (f) GFAP expression in cytoplasms. Nuclei are counterstained with DAPI (20× magnification); (g) Id. GalC (20× magnification); (h) Id. $\beta$-III Tubulin $(20 \times$ magnification). Observations were made on a Zeiss Axioskop fluorescence microscope equipped with an AxioCam5MR5c and coupled to an Imaging system (AxioVision Release 4.5, Zeiss). 


\section{CSCS AND THE TUMOR PHENOTYPE}

In our cell line series a correlation was found between NS generation in culture and the phenotype of primary tumors. This was characterized by the highest degree of malignancy with high cell density, high small vessel density, the highest proliferation index and the occurrence of necroses and of perivascular cuffings of tumor cells, expressing much more Nestin than GFAP, and other stemness antigens [33]. It could correspond to the intra-tumoral niches with hypoxic regions where CSCs are promoted or maintained [69-71]. The perivascular location of CSCs is in line with the close relationship among endothelial cells, Nestin and $\mathrm{CD} 133^{+}$cells, with the enhancement of their self-renewal by endothelial cells and the support of CSCs to the vasculature development [46]. This inter-relation might be read in an dynamic perspective, i.e. in a functional way, as if stemness may be transient and reversible and niche-dependent [72].

In general, quantitative differences in stemness properties, clonogenicity, tumorigenicity exist between NS and $\mathrm{AC}$ and within each category, corresponding to a kind of hierarchy of CSCs [16,37]. Stemness could be distributed in a spectrum covering all the tumor cells with a crescendo from quiescent highly differentiated cells, where it is nil, to those in which it reaches the highest degree of expression. As a matter of fact, either NS or AC grow in culture with different rates $[2,33]$ and the capacity to generate NS in culture conditions is not uniform for the different areas of GBM [24,33,73]. Areas increasingly different from the most malignant phenotype seem to progressively generate less NS or AC until to zero. Immature cells expressing Nestin, likely to be CSCs, have been found lining central necroses inside proliferating areas, where HIF-1 is highly expressed [73]; these sites may roughly correspond to those of the tumor where usually the highly malignant phenotype occurs. Practically, all the cells of a tumor are hierarchically distributed with respect to the capacity to produce NS in culture conditions or AC in serum condition. Obviously this does not resolve the question whether stem cells, at the top of the hierarchy represent a cell type or a functional status [66].

\section{SIGNIFICANCE OF THE STEM CELL STATUS AND THE ORIGIN OF GBM}

Of course, there are genetic determinants of stem cell identity and in the first row there is BMI1 which is believed to represent an oncogenic addition which distinguishes CSCs from NSCs [74,75]. Other pathways are Notch, Hedgehog, Bone morphogenetic protein (BMP), SRY (sex determining region Y)-box 2 (SOX2), Signal transducer and activator of transcription 3 (STAT3) [76-78] and c-MYC [79]. The regulatory factors can be activated or disactivated in the different contexts. In the conception that CSCs are the product of tumor cell dedifferentiation which follows mutation accumulation in the course of malignant transformation $[2,8,9]$, the reacquisition of stemness properties by the cells could be linked to the activation of the before mentioned pathways. At this point, the two GBM subtypes must be discussed as for their different origin.

Secondary GBM (sGBM) develops from a previous astrocytoma, whereas primary GBM (pGBM) is a de novo tumor. They differ as for the genetic configuration, age, and growth speed [80], but not for location and phenotype; at the most they can differ for the spreading modalities [9]. It is not known how de novo tumors arise, whereas it is believed that secondary ones originate through anaplasia, i.e. through dedifferentiation of tumor cells which follows mutation accumulation [81]. Generally, it is known that GBMs originate either from NSCs or from astrocytes [11] and this could correspond to the distinction between pGBMs and sGBMs. Obviously, it is likely that the two GBM subtypes must originate $a b$ initio from the same CSCs. The development of GBM in the emisphere, far away from the SVZ, could be in contrast with its origin from NSCs of the same region, but his can be got over if we refer to the concept of asymmetric division and of migration of progenitors [82]. A path has been traced from mitotically active precursors to the developed tumors [12], which recognizes in transiently dividing progenitors and in somatic stem cells the elements where mutations accumulate; they express also EGFR, present in normal progenitors of SVZ [83]. These cells are the possible source of pGBMs, whereas for sGBMs it is mandatory to refer to a previous astrocytoma.

The two GBM types differ for the expression of mutated Isocitrate dehydrogenase 1-2 (IDH1-2), occurring in sGBM, anaplastic and diffuse astrocytomas and oligodendrogliomas and not in pGBM $[84,85]$. The mutual exclusion of IDH mutations with EGFR amplification and its association with $1 \mathrm{p}-19 \mathrm{q}$ co-deletion, TP53 mutations and younger age [86-90] are relevant to the timing of IDH mutations, which must be placed between precursors and progenitors. All this means that sGBM originate from tumor cells which have already reached the site of tumor development and the stage of precursors, whereas pGBM originate from cells which transform by mutation accumulation during migration and before reaching the stage of progenitors; they reach the site of development already possessing the genetic equipment of malignancy and keeping or re-acquiring again, at the same time, the features of stem cells. This is something similar to the concept of "maturation arrest" [91] of cells that accumulate mutations and transform before reaching the full maturity or differentiation. 
(a)
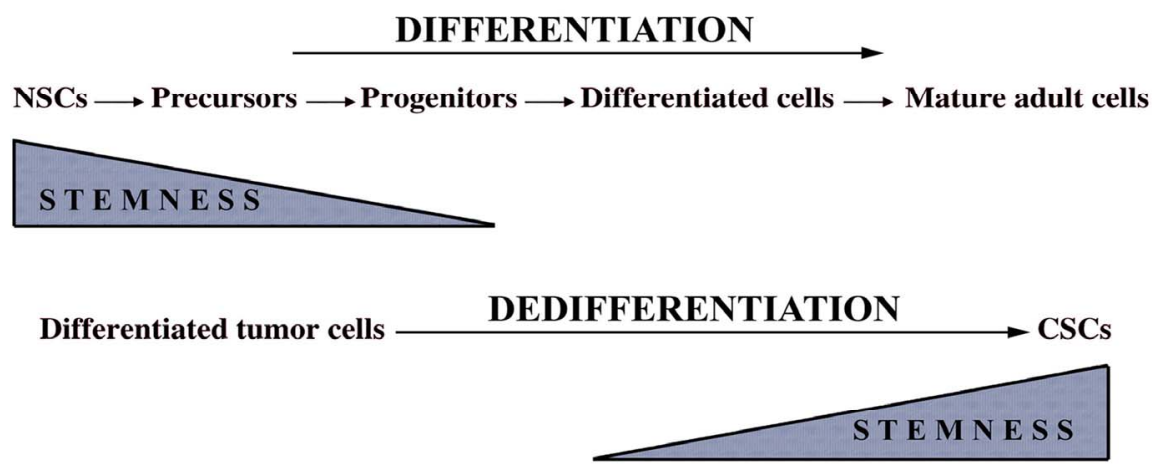

(b)

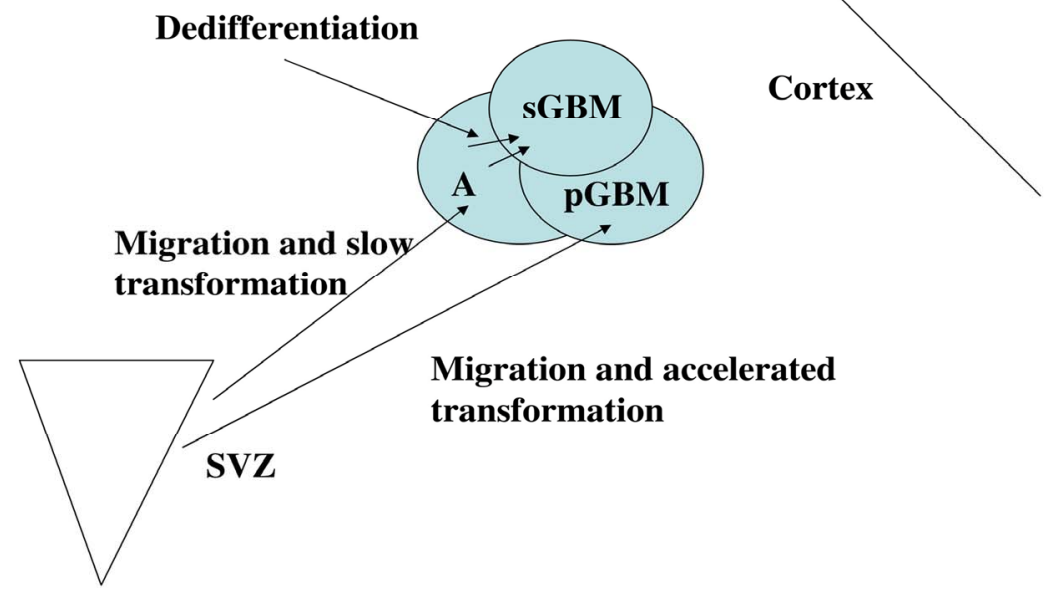

Figure 2. (a) Stemness in differentiation and dedifferentiation; (b) Origin of pGBM and sGBM.

The stemness properties would be acquired in sGBM by dedifferentiation and in pGBM by their preservation (Figure 2(a)). The process would be substantially the same, but more rapid and accelerated in pGBM, as already pointed out [17] (Figure 2(b)). Stemness would be a condition which is progressively lost during the normal nervous cytogenesis and progressively acquired during dedifferentiation in tumors. In sGBM to obtain NS in culture conditions would be more difficult, because few cells with dedifferentiation reach the stage of stemness, whereas in pGBM it is easier, because most cells already possess it. Stemness would be in this way more a transient status than a fixed feature of a given cell type. The microenvironmental influences are very important in modifying the stemness status, even conceiving GBM in a neo-darwinistic interpretation $[17,92]$.

\section{REFERENCES}

[1] Ignatova, T.N., Kukekov, V.G., Laywell, E.D., Suslov, O.N., Vrionis, F.D. and Steindler, D.A. (2002) Human cortical glial tumors contain neural stem-like cells expressing astroglial and neuronal markers in vitro. Glia, 39, 193-206. doi:10.1002/glia.10094

[2] Galli, R., Binda, E., Orfanelli, U., Cipelletti, B., Gritti, A., De Vitis, S., Fiocco, R., Foroni, C., Dimeco, F. and Vescovi, A. (2004) Isolation and characterization of tumorigenic, stem-like neural precursors from human glioblastoma. Cancer Research, 64, 7011-7021. doi:10.1158/0008-5472.CAN-04-1364

[3] Yuan, X., Curtin, J., Xiong, Y., Liu, G., WaschsmannHogiu, S., Farkas, D.L., Black, K.L. and Yu, J.S. (2004) Isolation of cancer stem cells from adult glioblastoma multiforme. Oncogene, 23, 9392-9400. doi:10.1038/sj.onc. 1208311

[4] Visvader, J.E. and Lindeman, G.J. (2008) Cancer stem cells in solid tumours: Accumulating evidence and unresolved questions. Nature Reviews Cancer, 8, 755-768. doi:10.1038/nrc2499

[5] Sanai, N., Alvarez-Buylla, A. and Berger, M.S. (2005) Neural stem cells and the origin of gliomas. New England Journal of Medicine, 353, 811-822. doi:10.1056/NEJMra043666

[6] Liu, Z., Hu, X., Cai, J., Liu, B., Peng, X., Wegner, M. and 
Qiu, M. (2007) Induction of oligodendrocyte differentiation by Olig2 and Sox10: Evidence for reciprocal interactions and dosage-dependent mechanisms. Developmental Biology, 302, 683-693. doi:10.1016/j.ydbio.2006.10.007

[7] Stiles, C.D. and Rowitch, D.F. (2008) Glioma stem cells: A midterm exam. Neuron, 58, 832-846. doi:10.1016/j.neuron.2008.05.031

[8] Vescovi, A.L., Galli, R. and Reynolds, B.A. (2006) Brain tumour stem cells. Nature Reviews Cancer, 6, 425-436. doi:10.1038/nrc1889

[9] Uchida, K., Mukai, M., Okano, H. and Kawase, T. (2004) Possible oncogenicity of subventricular zone neural stem cells: Case report. Neurosurgery, 55, 977-978. doi:10.1227/01.NEU.0000137891.99542.43

[10] Schiffer, D., Manazza, A. and Tamagno, I. (2006) Nestin expression in neuroepithelial tumors. Neuroscience Letters, 400, 80-85. doi:10.1016/j.neulet.2006.02.034

[11] Dai, C., Celestino, J.C., Okada, Y., Louis, D.N., Fuller, G.N. and Holland, E.C. (2001) PDGF autocrine stimulation dedifferentiates cultured astrocytes and induces oligodendrogliomas and oligoastrocytomas from neural progenitors and astrocytes in vivo. Genes \& Development, 15, 1913-1925. doi:10.1016/S1535-6108(02)00046-6

[12] Bachoo, R.M., Maher, E.A., Ligon, K.L., Sharpless, N.E., Chan, S.S., You, M.J., Tang, Y., DeFrances, J., Stover, E., Weissleder, R., Rowitch, D.H., Louis, D.N. and DePinho, R.A. (2002) Epidermal growth factor receptor and Ink4a/ Arf: Convergent mechanisms governing terminal differentiation and transformation along the neural stem cell to astrocyte axis. Cancer Cell, 1, 269-277. doi:10.1016/S1535-6108(02)00046-6

[13] Kelly, P.N., Dakic, A., Adams, J.M., Nutt, S.L. and Strasser, A. (2007) Tumor growth need not be driven by rare cancer stem cells. Science, 317, 337. doi:10.1126/science. 1142596

[14] Hadjipanayis, C.G. and Van Meir, E.G. (2009) Tumor initiating cells in malignant gliomas: Biology and implications for therapy. Journal of Molecular Medicine, 87, 363-374. doi:10.1007/s00109-009-0440-9

[15] Beier, D., Hau, P., Proescholdt, M., Lohmeier, A., Wischhusen, J., Oefner, P.J., Aigner, L., Brawanski, A. and Bogdahn, U. and Beier, C.P. (2007) CD133(+) and CD133(-) glioblastoma-derived cancer stem cells show differential growth characteristics and molecular profiles. Cancer Research, 67, 4010-4015. doi:10.1158/0008-5472.CAN-06-4180

[16] Chen, R., Nishimura, M.C., Bumbaca, S.M., Kharbanda, S., Forrest, W.F., Kasman, I.M., Greve, J.M., Soriano, R.H., Gilmour, L.L., Rivers, C.S., Modrusan, Z., Nacu, S., Guerrero, S., Edgar, K.A., Wallin, J.J., Lamszus, K., Westphal, M., Heim, S., James, C.D., VandenBerg, S.R., Costello, J.F., Moorefield, S., Cowdrey, C.J., Prados, M. and Phillips, H.S. (2010) A hierarchy of selfrenewing tumor-initiating cell types in glioblastoma. Cancer Cell, 17, 362-375. doi:10.1016/j.ccr.2009.12.049

[17] McLendon, R.E. and Rich, J.N. (2011) Glioblastoma stem cells: A neuropathologist's view. Journal of Oncology, 2011, Article ID: 397195. doi:10.1155/2011/397195

[18] Veeravagu, A., Bababeygy, S.R., Kalani, M.Y., Hou, L.C. and Tse, V. (2008) The cancer stem cell-vascular niche complex in brain tumor formation. Stem Cells and Development, 17, 859-867. doi:10.1089/scd.2008.0047

[19] Mirzadeh, Z., Merkle, F.T., Soriano-Navarro, M., GarciaVerdugo, J.M. and Alvarez-Buylla, A. (2008) Neural stem cells confer unique pinwheel architecture to the ventricular surface in neurogenic regions of the adult brain. Cell Stem Cell, 3, 265-278. doi:10.1016/j.stem.2008.07.004

[20] Shen, Q., Wang, Y., Kokovay, E., Lin, G., Chuang, S.M., Goderie, S.K., Roysam, B. and Temple, S. (2008) Adult SVZ stem cells lie in a vascular niche: A quantitative analysis of niche cell-cell interactions. Cell Stem Cell, 3, 289-300. doi:10.1016/j.stem.2008.07.026

[21] Coskun, V., Wu, H., Blanchi, B., Tsao, S., Kim, K., Zhao, J., Biancotti, J.C., Hutnick, L., Krueger, R.C. Jr., Fan, G., de Vellis, J. and Sun, Y.E. (2008) CD133 ${ }^{+}$neural stem cells in the ependyma of mammalian postnatal forebrain. Proceedings of the National Academy of Sciences of the United States of America, 105, 1026-1031. doi:10.1073/pnas.0710000105

[22] Holland, E.C., Celestino, J., Dai, C., Schaefer, L., Sawaya, R.E. and Fuller, G.N. (2000) Combined activation of Ras and Akt in neural progenitors induces glioblastoma formation in mice. Nature Genetics, 25, 55-57. doi:10.1038/75596

[23] Holland, E.C. (2001) Gliomagenesis: Genetic alterations and mouse models. Nature Reviews Genetics, 2, 120-129. doi: $10.1038 / 35052535$

[24] Hemmati, H.D., Nakano, I., Lazareff, J.A., Masterman-Smith, M., Geschwind, D.H., Bronner-Fraser, M. and Kornblum, H.I. (2003) Cancerous stem cells can arise from pediatric brain tumors. Proceedings of the National Academy of Sciences of the United States of America, 100 15178-15183. doi: $10.1073 /$ pnas. 2036535100

[25] Piccirillo, S.G., Combi, R., Cajola, L., Patrizi, A., Redaelli, S., Bentivegna, A., Baronchelli, S., Maira, G., Pollo, B., Mangiola, A., DiMeco, F., Dalprà, L. and Vescovi, A.L. (2009) Distinct pools of cancer stem-like cells coexist within human glioblastomas and display different tumorigenicity and independent genomic evolution. Oncogene, 28, 1807-1811. doi:10.1038/onc.2009.27

[26] Singh, S.K., Hawkins, C., Clarke, I.D., Squire, J.A., Bayani, J., Hide, T., Henkelman, R.M., Cusimano, M.D. and Dirks, P.B. (2004) Identification of human brain tumour initiating cells. Nature, 18432, 396-401. doi:10.1038/nature03128

[27] Yi, L., Zhou, Z.H., Ping, Y.F., Chen, J.H., Yao, X.H., Feng, H., Lu, J.Y., Wang, J.M. and Bian, X.W. (2007) Isolation and characterization of stem cell-like precursor cells from primary human anaplastic oligoastrocytoma. Modern Pathology, 20, 1061-1068. doi:10.1038/modpathol.3800942

[28] Alcantara Llaguno, S., Chen, J., Kwon, C.H., Jackson, E.L., Li, Y., Burns, D.K., Alvarez-Buylla, A. and Parada, L.F. (2009) Malignant astrocytomas originate from neural stem/progenitor cells in a somatic tumor suppressor mouse model. Cancer Cell, 15, 45-56. doi:10.1016/j.ccr.2008.12.006

[29] Facchino, S., Abdouh, M. and Bernier, G. (2011) Brain 
cancer stem cells: Current status on glioblastoma multiforme. Cancer, 3, 1777-1797. doi:10.3390/cancers3021777

[30] Schiffer, D. (1997) Brain tumors. Biology, pathology and clinical references. Springer, Berlin, Heidelberg, New York.

[31] Schiffer, D., Cavalla, P., Dutto, A. and Borsotti, L. (1997) Cell proliferation and invasion in malignant gliomas. Anticancer Research, 17, 61-69.

[32] Schiffer, D., Annovazzi, L., Caldera, V. and Mellai M. (2010) On the origin and growth of gliomas. Anticancer Research, 30, 1977-1998.

[33] Caldera, V., Mellai, M., Annovazzi, L., Piazzi, A., Lanotte, M., Cassoni, P. and Schiffer, D. (2011) Antigenic and genotypic similarity between primary glioblastomas and their derived neurospheres. Journal of Oncology, 2011, Article ID 314962. doi:10.1155/2011/314962

[34] Günther, H.S., Schmidt, N.O., Phillips, H.S., Kemming, D., Kharbanda, S., Soriano, R., Modrusan, Z., Meissner, H., Westphal, M. and Lamszus, K. (2008) Glioblastoma-derived stem cell-enriched cultures form distinct subgroups according to molecular and phenotypic criteria. Oncogene, 27, 2897-2909. doi:10.1038/sj.onc.1210949

[35] Lee, J., Kotliarova, S., Kotliarov, Y., Li, A., Su, Q., Donin, N.M., Pastorino, S., Purow, B.W., Christopher, N., Zhang, W., Park, J.K. and Fine, H.A. (2006) Tumor stem cells derived from glioblastomas cultured in bFGF and EGF more closelymirror the phenotype and genotype of primary tumors than do serum-cultured cell lines. Cancer Cell, 9, 391-403. doi:10.1016/j.ccr.2006.03.030

[36] Campos, B. and Herold-Mende, C.C. (2011) Insight into the complex regulation of CD133 in glioma. International Journal of Cancer, 128, 501-510. doi:10.1002/ijc. 25687

[37] Mazzoleni, S., Politi, L.S., Pala, M., Cominelli, M., Franzin, A., Sergi, L., Falini, A., De Palma, M., Bulfone, A., Poliani, P.L. and Galli, R. (2010) Epidermal growth factor receptor expression identifies functionally and molecularly distinct tumor-initiating cells in human glioblastoma multiforme and is required for gliomagenesis. Cancer Research, 70, 7500-7513. doi:10.1158/0008-5472.CAN-10-2353

[38] Nomura, T., Goritz, C., Catchpole, T., Henkemeyer, M. and Frisen, J. (2010) EphB signaling controls lineage plasticity of adult neural stem cell niche cells. Cell Stem Cell, 7, 730-743. doi:10.1016/j.stem.2010.11.009

[39] Son, M.J., Woolard, K., Nam, D.H., Lee, J. and Fine, H.A. (2009) SSEA-1 is an enrichment marker for tumor-initiating cells in human glioblastoma. Cell Stem Cell, 4, 440-452. doi:10.1016/j.stem.2009.03.003

[40] Cui, H., Ma, J., Ding, J., Li, T., Alam, G. and Ding, H.F. (2006) Bmi-1 regulates the differentiation and clonogenic self-renewal of I-type neuroblastoma cells in a concentration-dependent manner. The Journal of Biological Chemistry, 281, 34696-34704. doi:10.1074/jbc.M604009200

[41] Hayry, V., Tynninen, O., Haapasalo, H.K., Wolfer, J., Paulus, W., Hasselblatt, M., Sariola, H., Paetau, A., Sarna, S., Niemela, M., Wartiovaara, K. and Nupponen, N.N. (2008) Stem cell protein BMI-1 is an independent marker for poor prognosis in oligodendroglial tumours. Neuropathology and Applied Neurobiology, 34, 555-563. doi:10.1111/j.1365-2990.2008.00949.x

[42] Sanai, N., Tramontin, A.D., Quiñones-Hinojosa, A., Barbaro, N.M., Gupta, N., Kunwar, S., Lawton, M.T., McDermott, M.W., Parsa, A.T., Manuel-García Verdugo, J., Berger, M.S. and Alvarez-Buylla, A. (2004) Unique astrocyte ribbon in adult human brain contains neural stem cells but lacks chain migration. Nature, 427, 740744. doi:10.1038/nature02301

[43] Eriksson, P.S., Perfilieva, E., Björk-Eriksson, T., Alborn, A.M., Nordborg, C., Peterson, D.A. and Gage, F.H. (1998) Neurogenesis in the adult human hippocampus. Nature Medicine, 4, 1313-1317. doi:10.1038/3305

[44] Nunes, M.C., Roy, N.S., Keyoung, H.M., Goodman, R.R., McKhann, G. 2nd, Jiang, L., Kang, J., Nedergaard, M. and Goldman, S.A. (2003) Identification and isolation of multipotential neural progenitor cells from the subcortical white matter of the adult human brain. Nature Medicine, 9, 439-447. doi:10.1038/nm837

[45] He, X.C., Zhang, J. and Li, L. (2005) Cellular and molecular regulation of hematopoietic and intestinal stem cell behavior. Annals of the New York Academy of Sciences, 1049, 28-38. doi:10.1196/annals.1334.005

[46] Li, L. and Neaves, W.B. (2006) Normal stem cells and cancer stem cells: The niche matters. Cancer Research, 66, 4553-4557. doi:10.1158/0008-5472.CAN-05-3986

[47] Bao, S., Wu, O., McLendon, R.E., Hao, Y., Shi, Q., Hjelmeland, A.B., Dewhirst, M.W., Bigner, D.D. and Rich J.N. (2006) Glioma stem cells promote radioresistance by preferential activation of the DNA damage response. Nature, 444, 756-760. doi:10.1038/nature05236

[48] Folkins, C., Shaked, Y., Man, S., Tang, T., Lee, C.R., Zhu, Z., Hoffman, R.M. and Kerbel, R.S. (2009) Glioma tumor stem-like cells promote tumor angiogenesis and vasculogenesis via vascular endothelial growth factor and stromal-derived factor 1. Cancer Research, 69, 72437251. doi:10.1158/0008-5472.CAN-09-0167

[49] Jensen, R.L., Ragel, B.T., Whang, K. and Gillespie, D. (2006) Inhibition of hypoxia inducible factor-1alpha (HIF-1alpha) decreases vascular endothelial growth factor (VEGF) secretion and tumor growth in malignant gliomas. Journal of Neuro-Oncology, 78, 233-247. doi:10.1007/s11060-005-9103-Z

[50] Bar, E.E., Lin, A., Mahairaki, V., Matsui, W. and Eberhart, C.G. (2010) Hypoxia increases the expression of stemcell markers and promotes clonogenicity in glioblastoma neurospheres. American Journal of Pathology, 177, 14911502. doi:10.2353/ajpath.2010.091021

[51] Kourembanas, S., Hannan, R.L. and Faller, D.V. (1990) Oxygen tension regulates the expression of the platelet-derived growth factor-B chain gene in human endothelial cells. The Journal of Clinical Investigation, 86, 670-674. doi:10.1172/JCI114759

[52] Namiki, A., Brogi, E., Kearney, M., Kim, E.A., Wu, T., Couffinhal, T., Varticovski, L. and Isner, J.M. (1995) Hypoxia induces vascular endothelial growth factor in cultured human endothelial cells. The Journal of Biological Chemistry, 270, 31189-31195. 
doi:10.1074/jbc.270.52.31189

[53] Wang, R., Chadalavada, K., Wilshire, J., Kowalik, U., Hovinga, K.E., Geber, A., Fligelman, B., Leversha, M., Brennan, C. and Tabar, V. (2010) Glioblastoma stem-like cells give rise to tumour endothelium. Nature, 468, 829833. doi:10.1038/nature09624

[54] Ricci-Vitiani, L., Pallini, R., Biffoni, M., Todaro, M., Invernici, G., Cenci, T., Maira, G., Parati, E.A., Stassi, G., Larocca, L.M. and De Maria, R. (2010) Tumour vascularization via endothelial differentiation of glioblastoma stem-like cells. Nature, 468, 824-828. doi:10.1038/nature09557

[55] Aboody, K.S., Brown, A., Rainov, N.G., Bower, K.A., Liu, S., Yang, W., Small, J.E., Herrlinger, U., Ourednik, V., Black, P.M., Breakefield, X.O. and Snyder, E.Y. (2000) Neural stem cells display extensive tropism for pathology in adult brain: Evidence from intracranial gliomas. Proceedings of the National Academy of Sciences of the United States of America, 97, 12846-12851. doi:10.1073/pnas.97.23.12846

[56] Glass, R., Synowitz, M., Kronenberg, G., Walzlein, J.H., Markovic, D.S., Wang, L.P., Gast, D., Kiwit, J., Kempermann, G. and Kettenmann, H. (2005) Glioblastoma-induced attraction of endogeneous neural precursor cells is associated with improved survival. The Journal of Neuroscience, 25, 2637-2646. doi:10.1523/JNEUROSCI.5118-04.2005

[57] Ehtesham, M., Yuan, X., Kabos, P., Chung, N.H., Liu, G., Akasaki, Y., Black, K.L. and Yu, J.S. (2004) Glioma tropic neural stem cells consist of astrocytic precursors and their migratory capacity is mediated by CXCR4. Neoplasia, 6, 287-293. doi:10.1593/neo.03427

[58] Oh, M.C. and Lim, D.A. (2009) Novel treatment strategies for malignant gliomas using neural stem cells. $\mathrm{Neu}$ rotherapeutics, 6, 458-463. doi:10.1016/j.nurt.2009.05.003

[59] Diabira, S. and Morandi, X. (2008) Gliomagenesis and neural stem cells: Key role of hypoxia and concept of tumor "neo-niche". Medical Hypotheses, 70, 96-104. doi:10.1016/j.mehy.2007.04.024

[60] Russo, A.L., Kwon, H.C., Burgan, W.E., Carter, D., Beam, K., Weizheng, X., Zhang, J., Slusher, B.S., Chakravarti, A., Tofilon, P.J. and Camphausen, K. (2009) In vitro and in vivo radiosensitization of glioblastoma cells by the poly (ADP-ribose) polymerase inhibitor E7016. Clinical Cancer Research, 15, 607-612. doi:10.1158/1078-0432.CCR-08-2079

[61] Chalmers, A.J. (2010) Overcoming resistance of glioblastoma to conventional cytotoxic therapies by the addition of PARP inhibitors. Anticancer Agents in Medicinal Chemistry, 10, 520-533.

[62] Tamura, K., Aoyagi, M., Wakimoto, H., Ando, N., Nariai, T., Yamamoto, M. and Ohno, K. (2010) Accumulation of CD133-positive glioma cells after high-dose irradiation by Gamma Knife surgery plus external beam radiation. Journal of Neurosurgery, 113, 310-318. doi:10.3171/2010.2.JNS091607

[63] Facchino, S., Abdouh, M., Chatoo, W. and Bernier, G. (2010) BMI1 confers radioresistance to normal and can- cerous neural stem cells through recruitment of the DNA damage response machinery. The Journal of Neuroscience, 30, 10096-10111. doi:10.1523/JNEUROSCI.1634-10.2010

[64] Phillips, H.S., Kharbanda, S., Chen, R., Forrest, W.F., Soriano, R.H., Wu, T.D., Misra, A., Nigro, J.M., Colman, H., Soroceanu, L., Williams, P.M., Modrusan, Z., Feuerstein, B.G. and Aldape, K. (2006) Molecular subclasses of high-grade glioma predict prognosis, delineate a pattern of disease progression, and resemble stages in neurogenesis. Cancer Cell, 9, 157-173. doi:10.1016/j.ccr.2006.02.019

[65] Pollard, M., Yoshikawa, K., Clarke, I.D., Danovi, D., Stricker, S., Russell, R., Bayani, J., Head, R., Lee, M., Bernstein, M., Squire, J.A., Smith, A. and Dirks, P. (2009) Glioma stem cell lines expanded in adherent culture have tumor-specific phenotypes and are suitable for chemical and genetic screens. Cell Stem Cell, 4, 568-580. doi:10.1016/j.stem.2009.03.014

[66] Reynolds, B.A. and Vescovi, A.L. (2009) Brain cancer stem cells: Think twice before going flat. Cell Stem Cell, 5, 466-467. doi:10.1016/j.stem.2009.10.017

[67] Conti, L. and Cattaneo, E. (2010) Neural stem cell systems: Physiological players or in vitro entities? Nature Reviews Neuroscience, 11, 176-187. doi:10.1038/nrn2938

[68] Natsume, A., Kinjo, S., Yuki, K., Kato, T., Ohno, M., Motomura, K., Iwami, K. and Wakabayashi, T. (2011) Glioma-initiating cells and molecular pathology: Implications for therapy. Brain Tumor Pathology, 28, 1-12. doi:10.1007/s10014-010-0011-3

[69] Calabrese, C., Poppleton, H., Kocak, M., Hogg, T.L., Fuller, C., Hamner, B., Oh, E.Y., Gaber, M.W., Finklestein, D., Allen, M., Frank, A., Bayazitov, I.T., Zakharenko, S.S., Gajjar, A., Davidoff, A. and Gilbertson, R.J. (2007) A perivascular niche for brain tumor stem cells. Cancer Cell, 11, 69-82. doi:10.1016/j.ccr.2006.11.020

[70] Kaur, B., Khwaja, F.W., Severson, E.A., Matheny, S.L., Brat, D.J. and Van Meir, E.G. (2005) Hypoxia and the hypoxia-inducible-factor pathway in glioma growth and angiogenesis. Neuro-Oncology, 7, 134-153. doi: $10.1215 / \mathrm{S} 1152851704001115$

[71] Keith, B. and Simon, M.C. (2007) Hypoxia-inducible factors, stem cells, and cancer. Cell, 129, 465-472. doi:10.1016/j.cell.2007.04.019

[72] Zipori, D. (2004) The nature of stem cells: State rather than entity. Nature Reviews Genetics, 5, 873-878. doi:10.1038/nrg1475

[73] Persano, L., Rampazzo, E., Della Puppa, A., Pistollato, F. and Basso, G. (2011) The three-layer concentric model of glioblastoma: Cancer stem cells, microenvironmental regulation, and therapeutic implications. Scientific World Journal, 11, 1829-1841. doi:10.1100/2011/736480

[74] Felsher, D.W. (2008) Oncogene addiction versus oncogene amnesia: Perhaps more than just a bad habit? Cancer Research, 68, 3081-3086. doi:10.1158/0008-5472.CAN-07-5832

[75] Sharma, S.V. and Settleman, J. (2010) Exploiting the balance between life and death: Targeted cancer therapy and "oncogenic shock". Biochemical Pharmacology, 80, 
666-673. doi:10.1016/j.bcp.2010.03.001

[76] Kanamori, M., Kawaguchi, T., Nigro, J.M., Feuerstein, B.G., Berger, M.S., Miele, L. and Pieper, R.O. (2007) Contribution of Notch signaling activation to human glioblastoma multiforme. Journal of Neurosurgery, 106, 417-427. doi:10.3171/jns.2007.106.3.417

[77] Annovazzi, L., Mellai, M., Caldera, V., Valente, G. and Schiffer, D. (2011) SOX2 expression and amplification in gliomas and glioma cell lines. Cancer Genomics and Proteomics, 8, 139-147.

[78] Sherry, M.M., Reeves, A., Wu, J.K. and Cochran, B.H. (2009) STAT3 is required for proliferation and maintenance of multipotency in glioblastoma stem cells. Stem Cells, 27, 2383-2392. doi:10.1002/stem.185

[79] Kim, J., Woo, A.J., Chu, J., Snow, J.W., Fujiwara, Y., Kim, C.G., Cantor, A.B. and Orkin, S.H. (2010) A Myc network accounts for similarities between embryonic stem and cancer cell transcription programs. Cell, 143, 313-324. doi:10.1016/j.cell.2010.09.010

[80] Kleihues, P. and Ohgaki, H. (1999) Primary and seconddary glioblastomas: From concept to clinical diagnosis. Neuro Oncology, 1, 44-51.

[81] Louis, D.N., Ohgaki, H., Wiestler, O.D. and Cavenee, W.K. (2007) WHO classification of tumors of the central nervous system, 4th Edition, IARC, Lyon.

[82] Berger, F., Gay, E., Pelletier, L., Tropel, P. and Wion, D. (2004) Development of gliomas: Potential role of asymmetrical cell division of neural stem cells. The Lancet Oncology, 5, 511-514. doi:10.1016/S1470-2045(04)01531-1

[83] Doetsch, F., Petreanu, L., Caille, I., Garcia-Verdugo, J.M. and Alvarez-Buylla, A. (2002) EGF converts transit-amplifying neurogenic precursors in the adult brain into multipotent stem cells. Neuron, 36, 1021-1034. doi:10.1016/S0896-6273(02)01133-9

[84] Balss, J., Meyer, J., Mueller, W., Korshunov, A., Hartmann, C. and von Deimling, A. (2008) Analysis of the IDH1 codon 132 mutation in brain tumors. Acta Neuropathologica, 116, 597-602. doi:10.1007/s00401-008-0455-2

[85] Hartmann, C., Meyer, J., Balss, J., Capper, D., Mueller, W., Christians, A., Felsberg, J., Wolter, M., Mawrin, C., Wick, W., Weller, M., Herold-Mende, C., Unterberg, A., Jeuken, J.W., Wesseling, P., Reifenberger, G. and von
Deimling, A. (2009) Type and frequency of IDH1 and IDH2 mutations are related to astrocytic and oligodendroglial differentiation and age: A study of 1010 diffuse gliomas. Acta Neuropathologica, 118, 469-474. doi:10.1007/s00401-009-0561-9

[86] Sanson, M., Marie, Y., Paris, S., Idbaih, A., Laffaire, J., Ducray, F., El Hallani, S., Boisselier, B., Mokhtari, K., Hoang-Xuan, K. and Delattre J.Y. (2009) Isocitrate dehydrogenase 1 codon 132 mutation is an important prognostic biomarker in gliomas. Journal of Clinical Oncology, 27, 4150-4154. doi:10.1200/JCO.2009.21.9832

[87] Yan, H., Parsons, D.W., Jin, G., McLendon, R., Rasheed, B.A., Yuan, W., Kos, I., Batinic-Haberle, I., Jones, S., Riggins, G.J., Friedman, H., Friedman, A., Reardon, D., Herndon, J., Kinzler, K.W., Velculescu, V.E., Vogelstein, B. and Bigner, D.D. (2009) IDH1 and IDH2 mutations in gliomas. The New England Journal of Medicine, 360, 765-773. doi:10.1056/NEJMoa0808710

[88] Van den Bent, M.J., Dubbink, H.J., Marie, Y., Brandes, A.A., Taphoorn, M.J., Wesseling, P., Frenay, M., Tijssen, C.C., Lacombe, D., Idbaih, A., van Marion, R., Kros, J.M., Dinjens, W.N., Gorlia, T. and Sanson, M. (2010) IDH1 and IDH2 mutations are prognostic but not predicttive for outcome in anaplastic oligodendroglial tumors: A report of the European Organization for Research and Treatment of Cancer Brain Tumor Group. Clinical Cancer Research, 16, 1597-1604. doi:10.1158/1078-0432.CCR-09-2902

[89] Labussiere, M., Sanson, M., Idbaih, A. and Delattre, J.Y. (2010) IDH1 gene mutations: A new paradigm in glioma prognosis and therapy? Oncologist, 15, 196-199. doi:10.1634/theoncologist.2009-0218

[90] Mellai, M., Piazzi, A., Caldera, V., Monzeglio, O., Cassoni, P., Valente, G. and Schiffer, D. (2011) IDH1 and IDH2 mutations, immunohistochemistry and associations in a series of brain tumors. Journal of Neuro-Oncology, 105, 345-357. doi:10.1007/s11060-011-0596-3

[91] Cairncross, J.G. (1987) The biology of astrocytoma: Lessons learned from chronic myelogenous leukemia: Hypothesis. Journal of Neuro-Oncology, 5, 99-104. doi:10.1007/BF02571297

[92] Vineis, P. (2006) Misuse of genetic data in environmental epidemiology. Annals of the New York Academy of Sciences, 1076, 163-167. doi:10.1196/annals.1371.060 